\section{Controlled trial of cysteamine and dimercaprol after paracetamol overdose}

Clinical studies indicate that compounds containing a sulphydryl group protect against paracetamol-induced hepatic necrosis, 12 but there are few data on their relative efficacy. We report the results of the first controlled clinical trial comparing two such compoundsnamely, cysteamine (mercaptamine) and dimercaprol.

\section{Patients, methods, and results}

All 52 patients ( 34 women, 18 men) were seen within 10 hours after paracetamol overdose. Plasma paracetamol concentrations, measured by a rapid ether extraction method, fell above a line on a semilogarithmic graph joining values of $1.3 \mathrm{mmol} / 1(200 \mu \mathrm{g} / \mathrm{ml})$ two hours after ingesting the tablets and $0.5 \mathrm{mmol} / 1(80 \mu \mathrm{g} / \mathrm{ml}) 12$ hours after ingestion.

After gastric lavage and institution of supportive measures patients were allocated at random to treatment with cysteamine or dimercaprol, which was started within 12 hours of overdose. Infusions of cysteamine hydrochloride, freshly prepared for each patient, were administered intravenously through a Millipore filter $(0.22 \mu \mathrm{m})$ in a dose of $2 \mathrm{~g}$ in $20 \mathrm{ml}$ water. A further $1.2 \mathrm{~g}$ dissolved in $1500 \mathrm{ml} 5^{\circ}$, dextrose was given over the next 20 hours. Dimercaprol was administered by deep intramuscular injection in a dose of $4 \mathrm{mg} / \mathrm{kg}$ body weight four-hourly for 24 hours, then $3 \mathrm{mg} / \mathrm{kg}$ four-hourly for 24 hours.

In addition to serial liver function tests, liver biopsies were performed on 16 patients when their prothrombin times had returned to normal. The extent of hepatic necrosis was measured quantitatively by means of a morphometric technique ${ }^{3}$ without knowledge of the clinical background, and the results were expressed as the hepatocyte volume fraction. In 15 patients the total erythrocyte sulphydryl group concentration was estimated as an index of cellular stores. Estimations were made on admission and four- to eight-hourly over the next 24 hours.

In both treatment groups the mean interval between ingestion of tablets and admission was similar (cysteamine group $4.8 \pm 1 \mathrm{SE}$ of mean 0.5 hours, dimercaprol group $6.0 \pm 0.6$ hours), as was the mean time between overdose and treatment $(7.7 \pm 0.5$ hours and $7.9 \pm 0.6$ hours). There was no significant difference in mean initial plasma paracetamol concentrations (cysteamine group $2 \cdot 0 \pm 0 \cdot 1 \mathrm{mmol} / 1(295 \pm 19 \mu \mathrm{g} / \mathrm{ml})$, dimercaprol group $1.8 \pm 0.1 \mathrm{mmol} 1(269 \pm 17 \mu \mathrm{g} / \mathrm{ml}))$.

One patient, who received dimercaprol 12 hours after overdose, died after developing fulminant hepatic failure. None of the other patients developed hepatic encephalopathy.

Peak abnormalities in serum bilirubin concentrations and prothrombin times were significantly greater in patients treated with dimercaprol than in patients given cysteamine, and the severity of hepatic necrosis found on liver biopsy was also greater in the dimercaprol group (see table). The mean erythrocyte sulphydryl group concentration was not significantly different from normal in patients receiving cysteamine (cysteamine group $7.31+1 \mathrm{SE}$ of mean $1.0 \mathrm{mmol} / 1$; controls $8.04 \pm 0.28 \mathrm{mmol} / 1)$, but was significantly reduced in the dimercaprol group $(6.73 \pm 0.3 \mathrm{mmol} / 1 ; \mathrm{P}<0.01)$

Of the patients given cysteamine, all developed severe nausea and vomiting, six became drowsy, and one developed meningism, although lumbar puncture showed nothing abnormal. Patients receiving dimercaprol found the injections painful, and nine developed severe abdominal pain, which persisted throughout treatment. No permanent ill effects were associated with either regimen, however.

\section{Comment}

These results show that cysteamine affords greater protection than dimercaprol against hepatocellular necrosis after paracetamol overdose. This may be due to a higher intracellular bioavailability for cysteamine, since recipients of this compound maintained a higher erythrocyte sulphydryl group concentration than those given dimercaprol. The only death in this series occurred in a patient given dimercaprol 12 hours after overdose. We have seen two other patients who died in fulminant hepatic failure when cysteamine was given at 15-16 hours, and this emphasises the inefficacy ${ }^{1}$ and possible danger of treatment delayed beyond about 10 hours.

We gave patients a lower dose of cysteamine (equivalent to $2.17 \mathrm{~g}$ cysteamine base) than that used by other workers (equivalent to $3.6 \mathrm{~g}$ ), which may explain why biochemical abnormalities in our patients were greater than those in patients treated by Prescott $e t$ al. ${ }^{1}$ There was still a high incidence of unpleasant side effects, however, and we found cysteamine inconvenient to use. Methionine appears to be a promising substitute, ${ }^{5}$ and a controlled clinical study of its use is urgently needed.

We thank Dr G S Crockett, of Kettering and District General Hospital, and Dr D R K Medley, of Princess Alexandra Hospital, Harlow, for cooperating in this trial; Dr B Portmann for evaluating hepatic histology; and Linda Rimmer for editorial help. The support of Sterling-Winthrop Group is gratefully acknowledged.

1 Prescott, L F, et al, Lancet, 1976, 2, 109

2 Douglas, A P, Hamlyn, A N, and James, O, Lancet, 1976, 1, 111

${ }^{3}$ Weibel, E R, Kistler, G S, and Scherle, W F, Journal of Cell Biology, 1966, 30, 23.

4 Ellman, G L, Archives of Biochemistry and Biophysics, 1959, 82, 70.

${ }^{5}$ Crome, P, et al, Lancet, 1976, 2, 829.

(Accepted 26 fuly 1977)

Liver Unit, King's College Hospital and Medical School, London SE5 9RS

R D HUGHES, BSC, PHD, lecturer

B G GAZZARD, MD, MRCP, research fellow (present address: St Bartholomew's Hospital, London EC1)

M A HANID, MB, MRCP, research fellow

P N TREWBY, MA, MRCP, registrar

I M MURRAY-LYON, MD, MRCP, senior lecturer (present address: Charing Cross Hospital, London W6)

M DAVIS, MD, MRCP, senior lecturer and honorary consultant physician ROGER WILLIAMS, MD, FRCP, consultant physician and director of unit

Hull Royal Infirmary, Hull, Yorkshire

J R BENNETT, MD, FRCP, consultant physician

\section{Direct addition of small doses of insulin to intravenous infusion in severe uncontrolled diabetes}

Since 1973 various techniques of low-dose insulin administration in severe uncontrolled diabetes have been described, including intermittent intramuscular injection, continuous intravenous infusion using either a syringe pump or a separate paediatric giving set, and intermittent intravenous boluses. ${ }^{1}$

We describe here a simpler technique in which small insulin doses are added directly to the intravenous infusion bottle without the need for added albumin to prevent adsorption to the glass or polyethylene surfaces.

\section{Patients, methods, and results}

Twenty-one patients admitted with severe uncontrolled diabetes $(20$ with ketoacidosis and one with non-ketotic hyperglycaemia) were studied. They

Liver function values and proportion of surviving hepatocytes (expressed as $\%$ hepatocyte volume fraction; $(H V F)$ in patients receiving cysteamine and dimercaprol. Values are means $\pm 1 S E$ of mean

\begin{tabular}{|c|c|c|c|c|c|c|c|}
\hline & & & & $\begin{array}{c}\text { Maximum serum } \\
\text { bilirubin concentration } \\
(\mu \mathrm{mol} / \mathrm{l})\end{array}$ & $\begin{array}{l}\text { Maxinnum prothrombin } \\
\text { time ratio }\end{array}$ & $\begin{array}{c}\text { Maximum SGOT } \\
\text { concentration } \\
(\mathrm{IU} / \mathrm{l})\end{array}$ & $\underset{(\%)}{\text { HVF }}$ \\
\hline $\begin{array}{l}\text { Cysteamine group }(n=26) \\
\text { Dimercaprol group }(n=26)\end{array}$ & 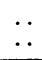 & $\begin{array}{ll}. . & . \\
. & . .\end{array}$ & .. & $\begin{array}{l}24 \pm 3 \\
54 \pm 14 \\
\end{array}$ & $\begin{array}{l}1.5 \pm 0.13 \\
2.1 \pm 0.35 \\
\end{array}$ & $\begin{array}{l}722 \pm 177 \\
754 \pm 170 \\
\end{array}$ & $\begin{array}{l}81 \cdot 0 \pm 4 \cdot 9 \\
61 \cdot 0 \pm 2 \cdot 4\end{array}$ \\
\hline$\overline{P(W i l c o x o n ' s ~ r a n k ~ s u m ~ t e s t) ~}$ & .. & .. & & $<0.05$ & $<0.05$ & NS & $<0.01$ \\
\hline
\end{tabular}


were aged 10 to 83 years (mean $37 \pm 5$ ) and four were newly diagnosed. Four had moderately impaired consciousness and three severely impaired consciousness. Thirteen had clinical evidence of precipitating infection. The initial plasma concentrations were as follows: glucose ranged from 17.5 to $65.0 \mathrm{mmol} / 1(315-1171 \mathrm{mg} / 100 \mathrm{ml})$ (mean $39.0 \pm 2.9 \mathrm{mmol} / 1(702 \pm 52$ $\mathrm{mg} / 100 \mathrm{ml})$ ); plasma bicarbonate $2.0-13.0 \mathrm{mmol}(\mathrm{mEq}) 1(7 \cdot 1 \pm 0.6 \mathrm{mmol} \mathrm{l})$ blood urea $3.5-25.9 \mathrm{mmol} / \mathrm{l}(127-156 \mathrm{mg} / 100 \mathrm{ml})(13.3+1.5 \mathrm{mmol}$ $(80 \cdot 1 \pm 9 \mathrm{mg} / 100 \mathrm{ml})$ ); plasma potassium $3 \cdot 2-7 \cdot 2 \mathrm{mmol}(\mathrm{mEq}) 1(5 \cdot 0 \pm 0 \cdot 2$ $\mathrm{mmol} / \mathrm{l})$; and plasma sodium $113-142 \mathrm{mmol}(\mathrm{mEq}) /(130 \cdot 4 \pm 1.7 \mathrm{mmol} 1)$. The arterial $\mathrm{H}$ concentration measured in eight patients was 69 to $118 \mathrm{nmol}(\mathrm{mEq}) / 1(95 \cdot 3+6.2 \mathrm{mmol} / \mathrm{l})$

The regimen-A loading dose of 2 units of soluble insulin was given intravenously. Soluble insulin was added direct to the drip bottle (or polyethylene container) to achieve an infusion rate of six units/h. Initial fluid replacement was given as saline $(0.154 \mathrm{~mol} / \mathrm{l})$, the infusion rate of 1.01 or 0.51 per hour depending on the degree of dehydration. This continued until the plasma glucose concentration had fallen to an arbitrary correction level less than $15 \mathrm{mmol} / 1(270 \mathrm{mg} / 100 \mathrm{ml})$. Dextrose $(50 \mathrm{~g} / \mathrm{l})$ was then substituted and the rate of insulin infusion halved to three units $h$ to prevent any further fall. Potassium chloride replacement was started immediately unless the initial plasma potassium was greater than $5.0 \mathrm{mmol} 1$. No patient needed treatment with sodium bicarbonate. Plasma insulin was measured in three of the newly diagnosed diabetics by specific radioimmunoassay

The mean hourly plasma glucose concentration fall ( $\pm \mathrm{SE}$ of mean) was $5.8 \pm 0.6 \mathrm{mmol} / 1(105+11 \mathrm{mg} / 100 \mathrm{ml})$. It took an average of $5.2 \pm 0.6$ hours for the concentration to reach less than $15 \mathrm{mmol} / 1$. The mean insulin dose given over this period was $32 \pm 4$ units (range (8-71). The mean time for correcting plasma bicarbonate (18 mmol/1 or greater) was $15 \cdot 2 \pm 1.2$ hours. The amounts of intravenous fluid given during correction of the plasma glucose and bicarbonate in the ketoacidotic patients were $3.7 \pm 0.41$ and $5.8 \pm 0.41$ respectively. The plasma potassium concentration was well maintained during treatment and the infusion concentration did not have to be increased above $20 \mathrm{mmol}$ per 0.51 . The cumulative amounts of potassium given at 6,12 , and 24 hours were $60 \pm 5,85 \pm 5$, and $114 \pm 7 \mathrm{mmol}$, respectively. Plasma insulin in the three patients not previously treated with insulin showed an initial concentration of $10 \pm 4 \mathrm{mU} / 1$ (range 6 to 18) with a rise to $76 \pm 24 \mathrm{mU} / 1$ (range 45 to 124 ) at 2 hours and $59 \pm 8 \mathrm{mU} / 1$ (range 46 to 72 ) after 4 hours. No complications occurred during treatment and all patients survived.

\section{Comment}

For several years we have treated diabetic ketoacidosis by adding insulin direct to the intravenous infusion drip bottle. ${ }^{2}$ The technique has been discouraged by reports that insulin is variably adsorbed to glass or polyethylene surfaces, although this effect is offset if albumin or other protein carrier is added. ${ }^{3}$ These additives are considered unnecessary if excessively dilute insulin solution-such as results when small amounts are added to the drip bottle-are avoided and the insulin is used in concentrated solution as with a syringe pump. ${ }^{1}$ We have shown, however, that when low-dose insulin was administered in dilute solution without the addition of albumin it was effective and insulin adsorption was not clinically important.

The rate of fall in plasma glucose concentration, the time to achieve correction of the plasma glucose, and the total amount of insulin given with our method were comparable with those with more elaborate techniques of low-dose insulin administration. In the three patients not previously treated with insulin the plasma insulin concentrations achieved were within the accepted physiological range and comparable with those obtained with the other techniques (see table).

Requests for reprints should be addressed to Dr B F Clarke.

${ }^{1}$ British Medical fournal, 1977, 1, 405

2 Duncan, L J P, in Textbook of Medical Treatment, 13th edn, ed S Alstead and $\mathrm{R}$ H Girdwood, p 363. Edinburgh and London, Churchill Livingstone, 1971.

${ }^{3}$ Kraegen, E W, et al, British Medical fournal, 1975, 3, 464

'Sönksen, P H, et al, Clinical Science and Molecular Medicine, 1973, 45, 633.

\section{(Accepted 4 August 1977)}

Diabetic and Dietetic Department and University Department of Medicine, Royal Infirmary, Edinburgh EH3 9YW

B F CLARKE, FRCP, consultant physician and senior lecturer

I W CAMPBELL, MRCP, senior registrar

D M FRASER, MRCP, senior registrar

E W BARNES, MRCP, senior registrar

N J DOUGLAS, MRCP, lecturer

I R STARKEY, BSC, MB, senior house officer

\section{Lithium intoxication induced by dieting and saunas}

Lithium is being increasingly used for long periods in the prophylaxis of recurrent affective illnesses. It has only a small margin of safety. Serum lithium concentrations between 0.7 and $1.2 \mathrm{mmol} / 1$ are aimed at, yet neurological toxic effects occur with concentrations around $2 \mathrm{mmol} / \mathrm{l}^{1}$ Irreversible neurological damage has been reported after serum concentrations of $2.3 \mathrm{mmol} / 1,2$ and with concentrations of $4 \cdot \mathrm{mmol} / \mathrm{l}$ patients are comatose and very ill.

Lithium may cause weight gain of $5 \mathrm{~kg}$ or more. ${ }^{1}$ This is often worsened by concurrent antidepressant drugs, which also cause weight gain. When this occurs patients may be tempted to diet drastically. This may be dangerous as fluid and salt restriction cause increases in serum lithium concentrations. ${ }^{3}$ The following case illustrates this danger.

\section{Case report}

A 60 -year-old man was being maintained on phenelzine, $15 \mathrm{mg}$ three times daily; tryptophan, $500 \mathrm{mg}$ at night; nitrazepam, $10 \mathrm{mg}$ at night ; and a delayed release preparation of lithium carbonate, $1 \mathrm{~g}$ a day. The results of serum lithium estimations seemed stable around $1 \cdot 1 \mathrm{mmol} / 1$. He was psychiatrically well but mildly obese.

He asked his psychiatrist if he could have treatment at a health farm for one week to lose weight. He was advised not to diet too vigorously and to

Comparison of previous low-dose insulin techniques 1973-76 with that of present study

\begin{tabular}{|c|c|c|c|c|c|c|c|c|c|c|c|c|}
\hline Author ${ }^{1}$ & & \begin{tabular}{|c|} 
Low-dose \\
insulin \\
technique
\end{tabular} & $\begin{array}{c}\text { No of } \\
\text { ketoacidotic } \\
\text { patients }\end{array}$ & $\begin{array}{c}\text { No of } \\
\text { non-ketotic } \\
\text { hypergly- } \\
\text { caemic } \\
\text { patients }\end{array}$ & $\begin{array}{c}\text { Mean } \\
\text { plasma } \\
\text { glucose } \\
(\text { mmol l) }\end{array}$ & $\begin{array}{l}\text { Insulin } \\
\text { loading } \\
\text { dose } \\
\text { (U) }\end{array}$ & $\begin{array}{l}\text { Insulin } \\
\text { hourly } \\
\text { dose } \\
\text { (U) }\end{array}$ & $\begin{array}{c}\text { Criterion for } \\
\text { plasma glu- } \\
\text { cose } \\
\text { correction } \\
(<\mathrm{mmol} / \mathrm{l})\end{array}$ & $\begin{array}{c}\text { Mean } \\
\text { plasma } \\
\text { glucose } \\
\text { fall } \\
(\mathrm{mmol} / \mathrm{l} / \mathrm{h})\end{array}$ & $\begin{array}{l}\text { Mean time } \\
\text { for plasma } \\
\text { glucose } \\
\text { correction } \\
\text { (h) }\end{array}$ & $\begin{array}{c}\text { Mean insulin } \\
\text { dose for } \\
\text { plasma } \\
\text { glucose } \\
\text { correction } \\
\text { (U) }\end{array}$ & $\begin{array}{l}\text { Plasma } \\
\text { insulin } \\
(\mathrm{mU} / \mathbf{l})\end{array}$ \\
\hline $\begin{array}{l}\text { Alberti et al } 1973 \\
\text { Moseley } 1975^{*} \\
\text { Kitabachi et al } 1976 \\
\text { Kidson et al } 1974 \\
\text { Page et al } 1974 \\
\text { Semple et al } 1974 \\
\text { Soler et al } 1975 \\
\text { Campbell et al } 1976 \\
\text { Clumeck et al } 1976 \\
\text { Malleson } 1976^{*} \quad \ldots \\
\text { Present study }\end{array}$ & $\begin{array}{l}\ldots \\
\cdots \\
\cdots \\
\cdots \\
\cdots \\
\cdots \\
\cdots \\
\cdots\end{array}$ & $\begin{array}{l}1 \\
1 \\
1 \\
2,3 \\
2 \\
2 \\
2 \\
3 \\
4 \\
4 \\
5\end{array}$ & $\begin{array}{r}14 \\
12 \\
24 \\
7 \\
31 \\
13 \\
18 \\
46 \\
19 \\
4 \\
20\end{array}$ & $\begin{array}{l}8 \\
4 \\
1\end{array}$ & 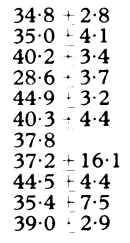 & $\begin{array}{c}16 \\
8 \\
13 \cdot 5 \\
0 \cdot 5 \\
0 \\
6 \cdot 5 \\
0 \\
0 \\
0 \\
10 \\
2\end{array}$ & $\begin{array}{l}5-10 \\
3-5 \\
5 \\
2 \cdot 4 \\
7 \cdot 2 \\
6 \cdot 5 \\
8 \\
2 \cdot 4 \\
5 \\
4 \\
6\end{array}$ & $\begin{array}{l}16 \cdot 6 \\
11 \cdot 1 \\
13 \cdot 8 \\
11 \cdot 0 \\
13 \cdot 8 \\
16 \cdot 6 \\
13 \cdot 8 \\
11 \cdot 1 \\
13 \cdot 8 \\
16 \cdot 6 \\
15 \cdot 0\end{array}$ & $\begin{array}{l}5 \cdot 1 \\
5 \cdot 3_{+}^{+} \\
4 \cdot 0_{+}^{+} \\
4 \cdot 2^{+} \\
8 \\
5 \cdot 6 \\
8 \\
3 \cdot 4 \\
4 \cdot 3 \\
3 \cdot 4_{+}^{+} \\
5 \cdot 8^{+}\end{array}$ & $\begin{array}{l}6 \cdot 5 \\
5 \cdot 3 \ddagger \\
6 \cdot 7 \\
4 \cdot 0 \ddagger \\
\$ \\
6 \cdot 5 \ddagger \\
5 \cdot 9 \\
8 \cdot 1 \\
8 \\
8 \cdot 3 \ddagger \\
5 \cdot 2\end{array}$ & $\begin{array}{l}43 \\
23 \\
45+5 \\
10_{+}^{+} \\
\S \\
39 \pm 7 \\
54 \pm 19 \\
\$ \\
\$ \\
35 \pm 6+ \\
32 \pm 4\end{array}$ & $\begin{array}{c}33-92 \\
\S \\
82 \pm 13 \\
36-143 \\
50-100 \\
75 \pm 8 \\
\S \\
\S \\
0->600 \\
68-188 \\
45-124\end{array}$ \\
\hline
\end{tabular}

*Studies in children.

$+1=$ Intermittent intramuscular injection. $2=$ Continuous intravenous infusion with syringe pump. $3=$ Continuous intravenous infusion with paediatric set. $4=$ Intermittent intravenous boluses. $5=$ Direct addition to infusion bottle.

tCalculated from authors' data. 